Instructions for authors, subscriptions and further details:

\title{
http://mcs.hipatiapress.com
}

\section{List of Reviewers}

Date of publication: February $21^{\text {th }}, 2019$

Edition period: February 2019-June 2019

To cite this article: MCS Editor (2019). List of Reviewers. Masculinities and Social Change, 8(1), 118. doi: 10.4471/MCS.2019.4100

To link this article: http://dx.doi.org/10.447/MCS.2019.4100

\section{PLEASE SCROLL DOWN FOR ARTICLE}

The terms and conditions of use are related to the Open Journal System and to Creative Commons Attribution License (CC-BY). 
MSC-Masculinities and Social Change Vol. 8 No. 1 February 2019 pp.118

\section{List of Reviewers}

I would like to thank all the scholars who served as reviewers in 2018. As the editor of the journal Masculinities and Social Change I am very grateful for the evaluations realized which have contributed to the quality of this journal.

Oriol Ríos

Editor

González, Victor Palmeiro, Ricardo

Solís, Daniel Castro, Marcos

Serrano, Maria Ángeles Roca, Esther

Martinez, Alejandro Castro-Herrera, Fabio Saul

Burke, Kevin Giner, Elisenda

Loureiro de Oliveira, José B Lopez, Laura

Schubert, Tinka

Villarejo, Beatriz

Girbés, Sandra

Cortés, Marta

Mara, Liviu

Amador, Jelen

Ionescu, Vladia

Campdepadrós, Roger

Laguna, Oscar

Williem, Cilia

Joanpere, Mar

Merodio, Guiomar

Aguayo, Francisco

Gairal, Regina 